\title{
SOCIAL INNOVATION IN TRADITIONAL NORWAY: BACKGROUND AND FEATURES
}

\begin{abstract}
When we hear someone say "Norway", in the imagination immediately emerges pictures of the ideal world: fairytale houses, bright green grass, picturesque nature, incredible fjords and wealthy and happy people. All in all, the above is the case in traditional Norway. This northwestern kingdom is perhaps the only state of its kind in which economic and political reforms are perfectly combined with social change and the evolutionary stages of civil society, giving what we now call the "ideal of socialism" model. However, it is quite obvious that the path to such a model was quite difficult; the Norwegians received their "ideal" state, through a total restructuring of their own consciousness, the creation of a unique system of upbringing of the younger generation, the belief in the common future of every Norwegian, which is both unique for each and for all. It is harder for a person who is not accustomed to hearing such postulates and, moreover, to live by following them, to grasp the whole content of these ideas. However, to make it easier to understand, there is only one fact: the gap between the very rich and the very poor in Norway is the lowest in the world. However, in Norway there is no such thing as "very poor". Like the "very rich" by the way. Every Norwegian lives in the community, following the ten so-called "Yanté laws", according to which "you, as an individual, do not exist; there is only a collective organism". And as in every normal healthy organism, all the components cooperate together for the sake of further health of that organism. Amazingly? Yes. Radically? Yes. But does it work? Yes. Following this logic, the Norwegians have built a practically ideal place where all migrants and the needy want to live. Norway has become a kind of "Eldorado" for residents of third and, what to hide, second world countries. The author suggests in this study to familiarize with the main components of Norwegian "ideal socialism", the preconditions that prompted the government to move in one way or another, as well as to list some of the most significant socially oriented innovative projects in Norway.
\end{abstract}

Keywords: Norway, social innovation, Yanté law, renewable energy, fisheries.

\section{INTRODUCTION}

The pacifist, democratic and extremely stable Scandinavian countries have always been a role model in Europe and the rest of the world. Social policy and economic development of the northern countries have shown their advantages over other systems in the world.

\section{FORMULATION OF THE PROBLEM}

Norway is a leader in the Scandinavian region by many indicators: life expectancy, well-being of citizens, economic growth, level of democratic rights, etc. Despite a number of tragic cases, including the terrorist act in Oslo and on the Norwegian island of Utea on July 22, 2011, committed by the multiculturalism opponent Anders Breivik, Norway remains one of the examples of a successful democratic state. For many years, it has been a leader in GDP per capita among European countries and in the world ( $4^{\text {th }}$ place) [1]. The Fjord country also ranks first in the UNDP Human Development Index [2]. Statistics can still be cited, but the main question still remains: what exactly contributed to such a significant separation of Norway from the rest of the world? What factors have played a key role in making this Scandina- vian country into one of the leaders in the social innovation sector? Let's try to answer this question further.

\section{OBJECTIVE}

The report proposes a brief excursion into the history of the Norway's birth as the sample of the twentieth century country and outline the key elements that have defined the current kingdom's course in innovation, in particular social orientation.

\section{ANALYSIS OF RESEARCH AND PUBLICATIONS}

The author used a number of sources with statistical material during the study of development and formation of social innovation in Norway, in particular, economic data on production, fluctuations in gross domestic product, the level of revenues to the state treasury from fisheries, the degree of pollution, etc. Some Norwegian social project websites have also been analyzed. Among them, public associations of cities, youth organizations, creative circles. In general, information on social projects in Norway and ways to innovate in the country's public life is sufficient. 


\section{RESULTS OF THE RESEARCH}

Innovation is at the heart of social, cultural, economic and technological change. At the most fundamental level, innovation can be understood as a process that involves generating new ideas, products and services and adopting, implementing and disseminating them. Almost all people - regardless of race, gender, age or social class - have the capacity to innovate. Driven by curiosity, creativity and empathy, people innovate when solving real-world problems, addressing personal and community needs, and influencing their local context.

Looking at the history and geography of the region, we can outline three main areas that have become fundamental to the development of modern Norwegian statehood:

- natural resources and "oil democracy";

- free citizenship: trust and equality;

- social innovation.

Let's look at each direction in more detail.

1. Natural resources and "oil democracy".

About $99 \%$ of all electricity produced in Norway comes from hydropower, one of the cleanest modern energy sources; in turn, renewable energy accounts for more than $60 \%$ of the country's total energy consumption. In addition, Norway has access to more than $50 \%$ of Europe's hydroelectric power plants through agreements, contracts, joint projects, etc. [3]. Norwegian company Statkraft, as a European leader in renewable energy, also exports its hydropower knowledge and experience, assists in the construction of green facilities around the world.

However, easy access to clean energy has its disadvantages, in particular, open access generates inappropriate and wasteful energy use. In fact, Norway is known for being one of the highest rated energy per capita. For comparison, the total area of Norway is 8 times bigger that the area of Switzerland, but the population of Switzerland is 8,4 million inhabitants, while Norway is only 5,2 million. At the same time, one third of the Norwegian region is hardly populated. However, this does not prevent to the Norwegians annually consume $26,000 \mathrm{kWh}$ per person, that is 3,25 times more than the average in Switzerland [4].

Another major source of energy is the oil and gas fields under the North Sea. Norway is selfsufficient in terms of natural gas and oil and does not need to import such resources.

When in 1969 a small kingdom with 3 million inhabitants began to exploit "black gold" after the opening of the Ekofisk oil field in the North Sea, Norway was one of the poorest countries in Europe. Today, the country is the world's $7^{\text {th }}$ largest oil exporter and the $3^{\text {rd }}$ largest gas exporter without being a member of OPEC [5]. There are a number of large crudes of oil and gas fields under the seabed that will provide the country with energy for the coming decades.

The state can charge only $4 \%$ of oil revenue each year. According to the Independent Financial Fund (Sovereign Wealth Fund), Norway's oil turnover is estimated at NOK 7 billion (around EUR 817 million) [6]. The share of oil in the fund accounts for about $1,3 \%$ of world capital turnover; in order to maintain a healthy investment situation in the economy, this fund invests more than 9,000 companies worldwide. Recently, however, the UN Ethics Commission has reviewed the activities of the Oil Independent Fund and found a large amount of inconsistency with the reports submitted. In particular, numerous human rights violations and environmental pollution were recorded. More than 60 oil-financed companies have been closed. Similar inspections were carried out in the future. Finally, on June 5, 2015, it was decided to close the Oil Independent Fund and liquidate all assets [6].

However, despite the "oil monopoly", strong positions of valuable energy resource occupy water resources. Rich fishing resources, an extremely long coastline, favorable ocean currents have accelerated the development of the marine industry in Norway, as nowhere else more.

Today, Norway owns $90 \%$ of the salmon market in the Atlantic Ocean and more than $50 \%$ in the Global oceans (since 2012, Norway has been supplying more than $60 \%$ of salmon on the world market annually) [7]. However, the rate of cultivation of this type of fish has caused a number of environmental problems, in particular the increase of the level of marine pollution (through the use of pesticides and persistent organic pollutants), especially on farms near the coastline, where the level of marine pollution is always higher. According to the Norwegian Environment Agency, emissions from a medium-sized business producing an average of 3120 tons of salmon per year are equivalent to annual emissions of a city with a population of $50,000[8]$.

The most critical situation is in the north, where the mining industry is directly "competing" with fisheries in terms of ecosystem destruction rates. Citizens do not stay on the sidelines, taking an active part in addressing environmental pollution. In particular, several Norwegian projects, such as Extractive Industries Transparency Initiatives or Green Warriors, are fighting for the protection of the Norwegian environment and the setting of much more restrictive and clear legal rules for the extractive industries in Norway.

\section{Free Citizenship: Trust and Equality.}

Norway is a social-democratic state. However, after the elections in 2013 and the coming to 
power of the Conservative Party, the government has embarked on a more liberal economic policy while maintaining strong social and environmental orientations. According to the Global Democracy Ranking, Norway has the highest level of democracy - the country has been in the first place for 5 years in a row [9].

Norway is a country of universal, inclusive wellbeing, equality of citizens and access to all rights and freedoms. The country financially helps its citizens: by decree on child-rearing, education, employment, health, retirement, etc. For example, after graduating from high school, students may enter the so-called People's School. Attending such a school does not imply traditional academic premises, classes, diplomas. However, here you can participate in the original training in nature.

In Norway, there are more than 80 "people's school": most of these schools provide the opportunity to play sports and recreation in the outdoors, as well as creativity, tourism, communication. Such schools are attended annually from 25 to $35 \%$ of young Norwegians, their tuition is paid by the state [10].

The state protects and supports a strong democratic system based on transparency and honesty, simplicity and pragmatism. Very often, to describe the Scandinavian mentality, they use the postulates of the so-called "Law of Yant " (from Norwegian "Janteloven"). This document is a collection of rules formulated by writer Aksel Sandemose in his novel "The Fugitive Crosses Its Trail", published in 1933, according to which society does not recognize the rights of its members to individuality [11]. The novel sets out 10 rules that society follows. They can all be combined into one: "don't think you're special". Therefore, in traditional Norway, it is not customary to attract, praise or attach special importance to your achievements.

That is why, money in Norway is not an end in itself, they do not appear in corruption schemes (because such schemes are practically absent in the country), they are not a cause of conflict (as in most countries of the world). Norwegian society is a "society of trust"; it is characterized by a higher level of transparency in all spheres of public life for elected officials and entrepreneurs as well as for ordinary citizens. In particular, the wage gap between the least skilled worker in the enterprise and the CEO of the firm remains one of the smallest company in the world. This attitude demonstrates the strong social cohesion of the country and the result of a long tradition of social economy.

The Norwegian economy is based on tax transparent contributions from individuals and legal entities. All content is displayed on the Internet, anyone can read the information. The situation here is absolutely unknown when citizens flee the country, taking on the citizenship of another state, in order to avoid paying taxes (as is common, for example, in France).

According to recent research, Norway has one of the lowest unemployment rates in the world about $4 \%$ [12]. However, according to the Organization for Economic Co-operation and Development, Norway occupies such a high position to a large extent due to social unemployment benefits, primarily to migrants. However, in Norway, the number of upper-middle-income citizens is one of the largest in the world compared to lowerincome citizens.

This approach to education of youth and population involvement has its consequences: the higher the level of the economy in a country, the more expensive it becomes. This applies to all areas of life: the price of products, rental housing, clothing, medicine, transportation, etc. A more detailed situation can be considered in Fig. 1.

Based on the data shown in Fig. 1, as well as evaluating similar data from previous years, we can state that Norway has been one of the most expensive countries in the world for many years, which clearly shows the high level of development of its economic system.

3. Social Innovation.

Before going into the analysis of the state of social innovation in Norway, it is necessary to familiarize with the general situation in the country. Thus, according to the information presented in the ranking of the Global Innovation Index in 2018, Norway closes the second ten countries with the highest indicators of innovation (Table 1).

Norway has an average innovation score. It is difficult to clearly explain why this happened. There are a number of reasons. However, the main point is that practically all the latest solutions and innovations have already been implemented in the country, so now it does not feel a particular need for so-called "innovation races". And it is paying more attention to social innovation, establishing itself as a welfare state with a high culture of charity.

Social innovation changes depending on the local context and cultural values of different communities. In Norway, a welfare state with a high level of involvement in social and environmental responsibility, social innovation is carried out by many actors. Moreover, in this situation, social innovation is often supported by both the public and private sectors. Despite being a high-level social development country (ranked first in the UN index) and free, universal access to high quality services (such as education, health), there are a number of problems in Norway. Social issues are addressed (for example, the exclusion of disad- 


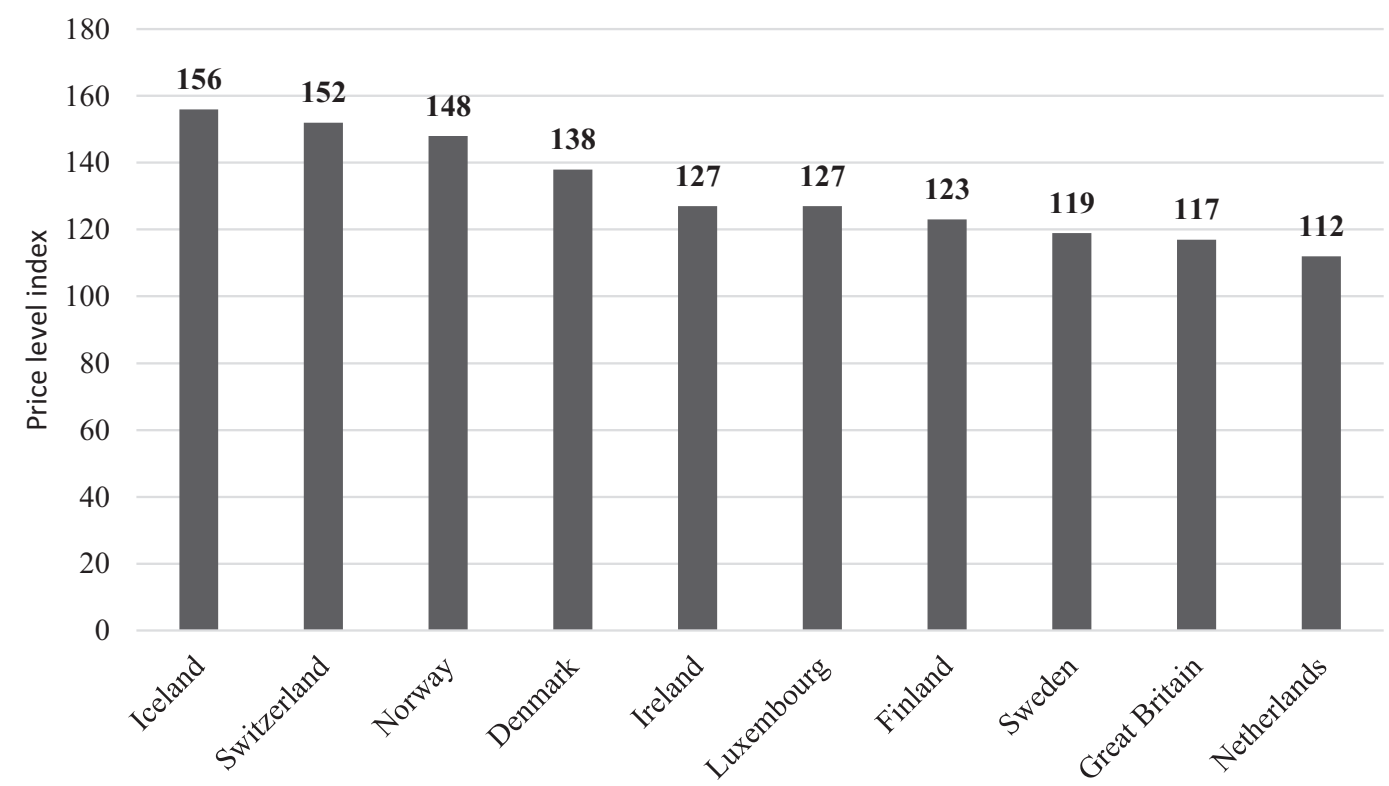

Fig. 1. The most expensive countries in the world in 2018 (Eurostat data)

Source: compiled by the author based on the data: Price level index for final household consumption expenditure (HFCE) 2018, Eurostat. Statistics Explained. - Retrieved from: https://ec.europa.eu/eurostat/statistics-explained/index. php?title=File:Price_level_index_for_final_houshold_consumption_expenditure_(HFCE)_2018,_(EU-28\%3D100).png\#filelinks [13]

Table 1

Global Innovation Index 2018 (compared to 2017)

\begin{tabular}{|c|l|c|c|c|}
\hline No (2018) & \multicolumn{1}{|c|}{ Country } & Score & No (2017) & Score \\
\hline \hline 1 & Switzerland & 68.40 & 1 & 67.69 \\
\hline 2 & Netherlands & 63.32 & 3 & 63.36 \\
\hline 3 & Sweden & 63.08 & 2 & 63.82 \\
\hline 4 & Great Britain & 60.13 & 5 & 60.89 \\
\hline 5 & Singapore & 59.83 & 7 & 58.69 \\
\hline 6 & United States & 59.81 & 4 & 61.40 \\
\hline 7 & Finland & 59.63 & 8 & 58.49 \\
\hline 8 & Denmark & 58.39 & 6 & 58.70 \\
\hline 9 & Germany & 58.03 & 9 & 58.39 \\
\hline 10 & Ireland & 57.19 & 10 & 58.13 \\
\hline $\mathbf{1 9}$ & Norway & $\mathbf{5 2 . 6 3}$ & $\mathbf{1 8}$ & $\mathbf{5 3 . 1 4}$ \\
\hline
\end{tabular}

Source: compiled by the author based on the data: The Global Innovation Index 2017. WIPO Data. - Retrieved from: https://www.wipo.int/edocs/pubdocs/en/wipo_pub_gii_2017.pdf [14] The Global Innovation Index 2018. WIPO Data. Retrieved from: https://www.wipo.int/edocs/pubdocs/en/wipo_pub_gii_2018.pdf [15]

vantaged groups and the gender gap in learning outcomes).

Given the strong culture of volunteering that exists in Norway, people find multiple opportunities for collaborating and solving real-world problems. There is even a word in the Norwegian language for describing volunteer work: "dugnad." This term refers to work that is done without payment, voluntar- ily, in groups, and usually rewarded with food and drink. "Dugnad" (from Eng. - "Voluntary work") is part of a Norwegian ancient tradition in which people work together to complete tasks such as outdoor spring cleaning, gardening, and building houses [16].

The concept of an ecosystem is useful for understanding and modeling the complex processes 
that take place in our social world, including innovation.

In Norway, a so-called system (or rather a strategy) was developed to measure entrepreneurial activity. It includes four indicators: concentration, flexibility, interconnection i diversity. Each metric has three quantitative variables. For example, diversity can be measured using statistics on immigration, social mobility and economic specialization. This strategy is described in more detail in Table 2.

After introducing the structure of the ecosystem and explaining its application, it is possible to consider the types of community activity that are exemplary of the Norwegian version of social innovation. They are as follows:

Human capital assets: skills, knowledge, experiences, and leadership capacities. Examples: academic experience/education level, computer skills, organizing skills, spoken languages.

Technological assets: the technologies used for producing and circulating ideas, products, and services. Tools for managing communities, building networks. Examples: computers, mobile devices, multimedia software, social media.

Economic assets: the institutions and organizations that cultivate or support innovation. Examples: incubators, financiers, venture capitalists, business support services, accelerators, proofof-concept centers, universities, grants, charities.

Physical assets: the spaces (public and private) that stimulate new and higher levels of connectivity, collaboration, and innovation. Example: co-working spaces, libraries, old buildings.

Social capital assets: the relationships between all the elements of the ecosystem (actors, resources, institutions). Relationships have the potential to generate opportunities to make new social ties, access new resources. Examples: networks, partnerships, mentorships, friendships, or other associations.

Legal and regulatory assets: the local laws and regulations that support innovation and entrepreneurship in a society. Examples: business and property rights, labor laws, tax rates and incentives, government services [16].

All positive, "social" solutions in Norway have led to the emergence of a phenomenon such as "social innovation". In general, it has historically happened that any country at some stage in its development must address the following question: what way to move on - through national economic prosperity or through civil society. The vast majority of Western countries, as well as countries in other regions, have chosen this or that path of development. In Norway this has not happened. In the

Norwegian version of "social innovation" of the country

\begin{tabular}{||l|l|l||}
\hline \multicolumn{1}{|c|}{ Indicator } & \multicolumn{1}{|c|}{ Components } & \multicolumn{1}{c|}{ Possible sources } \\
\hline \hline \multirow{5}{*}{ Concentration } & $\begin{array}{l}\text { The emergence of new firms per } \\
1,000 \text { people }\end{array}$ & $\begin{array}{l}\text { Databases, statistics of business } \\
\text { dynamics }\end{array}$ \\
\cline { 2 - 3 } & $\begin{array}{l}\text { Exchange of employees between new } \\
\text { firms }\end{array}$ & $\begin{array}{l}\text { Databases, statistics of business } \\
\text { dynamics }\end{array}$ \\
\cline { 2 - 3 } & $\begin{array}{l}\text { The niche occupancy of the sector, } \\
\text { especially high-tech components }\end{array}$ & $\begin{array}{l}\text { Institutions subordinate to the } \\
\text { authorities }\end{array}$ \\
\hline \multirow{5}{*}{ Flexibility } & Population flow & Internal Revenue Service \\
\cline { 2 - 3 } & Redistribution of the labor market & Quarterly figures of labor \\
\cline { 2 - 3 } & Fast-growing companies & Databases \\
\hline & Communication of various programs & Projects under development \\
\cline { 2 - 3 } & Side projects & Social networks \\
\cline { 2 - 3 } & Dealer networks & Other sources of personal information \\
\hline \multirow{2}{*}{ Diversity } & Several economic specializations & $\begin{array}{l}\text { Quarterly census of employment and } \\
\text { wages }\end{array}$ \\
\hline & Social Mobility & Equal Opportunities Projects \\
\hline & Immigrants & Survey of the population \\
\hline
\end{tabular}

Source: compiled by the author based on the data: 16. Exploring Social Innovation in Norway: A Workshop on Mapping Innovation Ecosystems. Berkman Klein Center. Retrieved from: https://medium.com/berkman-klein-center/exploringsocial-innovation-in-norway-a-workshop-on-mapping-innovation-ecosystems-c82bcc1b58a6 [16] 
country there was a simultaneous development of social innovations together with state-regulated measures. In the course of evolutionary changes, several key players stood out in this area, including:

1. A number of interesting public organizations and institutions have been established in the capital city - Oslo. Coworking Center "SoCentral" [17] brings together 70 members - entrepreneurs and ordinary residents of the city - working in various sectors of the industry, from healthcare, education, wellness, nutrition to transportation and construction. "SoCentral" also works as a platform for social business, offering consulting services to the public sector, and plays the key role of mediator between the state and legal entities in it. Public Association "Epleslang" [18] — is a social integration company that requires a reduction in food waste during the manufacturing process. An interesting initiative of the association is to grow apples at home (in private plots, in villages) and further processing them into $100 \%$ natural juice without impurities and dyes. The firm "Kooperativet" (Eng. - "The cooperative") is a leader in local organic produce sales in the food industry [19]. Network Open Food [20] was recently established in Norway. Its mission is to facilitate communication between producers and consumers, thereby reducing the need for intermediaries. In the education sector, it is worth mentioning the company "Bua" [21], the main focus of which is to reduce social inequalities in health care for young people and children. Children's circle "Abildsø skolegård" (Eng. - "School yard "Abildsø") [22] positions itself as an "agricultural training ground"; according to the group's founders, "spending time on the farm as an educational tool for children and young people will help reduce children's cravings for bad habits and bad companies". Organization "Pøbelprosjektet AS" (Eng. - "Project "Pøbel") [23] aimed at helping young people outside the established education system and the labor market. A group of enthusiasts called "Forskerfabrikken" (Eng. - "Researcher's factory" [24] helps young scientists and inventors rebuild their scientific development in Norway.

2. Bergen, Norway's second largest city, has a network "Impact Hub" [25]; there are several social enterprises based on it. Including "Baerkraftige liv pâ landâs" (Eng. - "Sustainable life on land" [26] - an association inspired by the "moving cities" movement - the voluntary movement of citizens to sparsely populated regions of the country. The main activities of the Association are to support and promote the development of a sustainable food system, a common economy, clean transport and sustainable housing.

3. The city of Stavanger, Norway's oil capital, is also known by the recently created Association
"Urban Sjofront" [27], which aims to further develop Stavanger as a "positive city", moving away from the glory of the "oil treasure" of the country. The Association works closely with local residents, business owners and elected officials. Together, they address urban planning and housing, open access to utilities for all citizens, free education, a clean environment, etc. Close contact of citizens from different segments of the population, with different interests and specialties led to the construction of so-called "communal" (or cooperative) housing. The index of such cooperatives in Stavanger is the largest among other cities in Norway.

\section{CONCLUSIONS}

Today, it is difficult to pinpoint exactly when the turning point came, when a key decision was made, an important reform was carried out, in short, what made the Kingdom of Norway a leader in social development in Europe and the world. The following can be said precisely: a clear, planned and balanced economic policy, the right political decisions, a solid civic position of the Norwegians created for Norway a chance to become not just another country in the Northern region of Europe. Norway's "social paradise" has become real thanks to the continuous and continuous cooperation of the state, production and society in order to make all the best social innovations for every citizen of the country a reality.

And as always, traditional advice for Ukraine: it is not about a complete replication of the Norwegian experience in innovating the social component of the state; however, the power and responsibility of the national power-holders should take on the experience of the Scandinavian country in transforming its own natural resources and historical features into its own advantages and "weapons" in the fight for a better future for its citizens.

\section{REFERENCES}

1. Gross domestic product (GDP). OECD Data. Retrieved from: https://data.oecd.org/gdp/gross-domestic-product-gdp.htm

2. Human Development Indices and Indicators. 2018 Statistical Update. UNPD Data. Retrieved from: http://hdr.undp.org/sites/default/files/2018_human_development_statistical_update.pdf; https:// doi.org/10.18356/9a42b856-en

3. Hydropower. Statkraft. Retrieved from: https://www. statkraft.com/energy-sources/hydropower/

4. Switzerland - Electric power consumption (kWh per capita). Trading Economics Data. Retrieved from: https://tradingeconomics.com/switzerland/electricpower-consumption-kwh-per-capita-wb-data.html

5. Portal vneshneekonomicheskoy informatsii [Foreign Economic Information Portal]. Retrieved from: http://www.ved.gov.ru/

6. The government's revenues. Norwegian Petroleum. Retrieved from: https://www.norskpetroleum.no/ en/economy/governments-revenues/ 
7. The Norwegian aquaculture analysis 2017. EY Data Retrieved from: https://www.ey.com/Publication/ vwLUAssets/EY - The Norwegian_Aquaculture Analysis_2017/\$F FILE/EY-Norwegian-AquacultureAnalysis-2017.pdf

8. Om Miljødirektoratet [About the Environment Directorate]. Miljødirektoratet. Retrieved from: http:// www.miljodirektoratet.no/no/Om-Miljodirektoratet/ Norwegian-Environment-Agency/

9. The Economist Intelligence Unit's Democracy Index. The Economist Infographics Data. Retrieved from: https://infographics.economist.com/2018/Democracylndex/

10. Hva vil du bruke året ditt på? [What do you want to spend your year on?]. Folkehøgskole. Retrieved from: https://www.folkehogskole.no/

11. 8 neozhidannyih faktov o vospitanii v Norvegii [8 unexpected facts about education in Norway]. Kolobok.ua. Retrieved from: https://kolobok.ua/ semya/vospitanieЗакон\%20Янте:\% 208\%20 неожиданных\% 20фактов\% $200 \% 20$ воспитании \%20в\%20Норвегии.html

12. Unemployment. Country Economy Data. Retrieved from: https://countryeconomy.com/unemployment

13. Price level index for final household consumption expenditure (HFCE) 2018, Eurostat. Statistics Explained. Retrieved from: https://ec.europa.eu/eurostat/statistics-explained/index.php?title=File:Price_level_index_for_final_houshold_consumption_expenditure (HFC̄E)_2018,_(EU-28\%3̄D100).png\#filelinks; https:// doi.org/10.1787/eco_surveys-che-2017-graph52-en
14. The Global Innovation Index 2017. WIPO Data. Retrieved from: https://www.wipo.int/edocs/pubdocs/ en/wipo_pub_gii_2017.pdf

15. The Global Innovation Index 2018. WIPO Data. Retrieved from: https://www.wipo.int/edocs/pubdocs/ en/wipo_pub_gii_2018.pdf

16. Exploring Social Innovation in Norway: A Workshop on Mapping Innovation Ecosystems. Berkman Klein Center. Retrieved from: https://medium.com/berkman-klein-center/exploring-social-innovation-innorway-a-workshop-on-mapping-innovation-ecosystems-c82bcc 1 b58a6

17. SoCentral. Retrieved from: https://www.socentral.no/

18. Eplestang. Retrieved from: http://epleslang.com/

19. Oslo Kooperativ. Retrieved from: http://kooperativet. no/

20. Open Food Network. Retrieved from: https://openfoodnetwork.org/

21. BUA. Retrieved from: https://www.bua.io/

22. Abildsø skolegård [School yard "Abildsø"]. Retrieved from: http://www.skolegaard.org/

23. Pøbelprosjektet AS [Project "Pøbel"]. Retrieved from: http://pobelprosjektet.no/

24. Forsker-Fabrikken [Researcher's factory]. Retrieved from: https://www.forskerfabrikken.no/

25. Bergen Impact Hub. Retrieved from: https://bergen. impacthub.net/

26. Baerkraftige liv pâ landâs [Sustainable life on land]. Retrieved from: https://www.barekraftigeliv.no/

27. Urban Sjofront. Retrieved from: http://urbansjofront. no/.

\section{I. С. БАЛАНЧУК, С.Н.С.}

\section{СОЦІАЛЬНІ ІННОВАЦІЇ В ТРАДИЦІЙНІЙ НОРВЕГІЇ: ПЕРЕДУМОВИ ТА ОСОБЛИВОСТІ}

Резюме. Коли ми чуємо, як хтось каже "Норвегія", то в уяві одразу постають картини ідеального світу: казкові будиночки, яскраво зелена трава, мальовнича природа, неймовірні фіорди і заможні та щасливі люди. Загалом усе вищеперераховане має місце в традиційній Норвегії. Це північно-західне королівство є, мабуть, єдиною у своєму роді державою, у якій економічні та політичні реформи ідеально поєдналися з суспільними змінами й еволюційними ступенями громадського суспільства, даючи на виході те, що сьогодні ми називаємо "модель ідеального соціалізму". Цілком очевидно, що шлях до такої моделі був досить нелегким. Норвежці отримали свою "ідеальну” державу шляхом тотальної перебудови власної свідомості, створення унікальної системи виховання підростаючого покоління, віри в спільне майбутнє кожного норвежця, яке є єдиним водночас і для кожного, і для усіх. Людині, яка не звикла чути такі постулати і, тим паче, жити, дотримуючись їх, тим важче осягнути увесь зміст цих ідей. Однак для полегшення розуміння варто навести лише один факт: розрив між дуже багатими і дуже бідними в Норвегії найнижчий у всьому світі. Варто зауважити, що в Норвегії взагалі не існує такого поняття, як "дуже бідний”, як і “дуже багатий”, до речі. Кожен норвежець живе в суспільстві, дотримуючись десяти "законів Янте", за якими "тебе, як індивідуальності, не існує; є лише колективний організм". I як у кожному нормальному здоровому організмі всі складові співпрацюють разом заради подальшого здоров'я цього організму. Дивно? Так. Радикально? Так. Але це працює? Так. Саме відповідно до такої логіки, норвежці побудували практично ідеальне місце, де хочуть жити усі, куди прагнуть мігранти та знедолені. Норвегія стала таким собі “Ельдорадо” для жителів країн третього, та й другого світу. Автор пропонує в цій статті ознайомитися з головними складовими норвезького “ідеального соціалізму", передумовами, що спонукали керівництво держави рухатися тим чи іншим шляхом, а також перерахувати деякі найбільш значущі соціально зорієнтовані інноваційні проєкти Норвегії.

Ключові слова: Норвегія, соціальні інновації, закон Янте, відновлювальна енергетика, рибальство.

\section{И. С. БАЛАНЧУК, С.Н.С.}

\section{СОЦИАЛЬНЫЕ ИННОВАЦИИ В ТРАДИЦИОННОЙ НОРВЕГИИ: ПРЕДПОСЫЛКИ И ОСОБЕННОСТИ}

Резюме. Когда мы слышим, как кто-то говорит “Норвегия”, то в воображении сразу же возникают картины идеального мира: сказочные домики, ярко зеленая трава, живописная природа, невероятные фьорды и состоятельные и счастливые люди. В целом, все вышеперечисленное имеет место быть в традиционной Норвегии. Это северо-западное королевство является, пожалуй, единственной в своем роде страной, в которой экономические и политические реформы идеально сочетаются с общественными изменениями и 
эволюционными ступенями гражданского общества, давая на выходе то, что сегодня мы называем "моделью идеального социализма". Совершенно очевидно, что путь к такой модели был достаточно нелегким. Норвежцы получили свое "идеальное” государство путем тотальной перестройки собственного сознания, создания уникальной системы воспитания подрастающего поколения, веры в общее будущее каждого норвежца, которое является единственным одновременно и для каждого, и для всех. Человеку, который не привык слышать такие постулаты и, тем более, жить, соблюдая их, тем труднее понять весь смысл этих идей. Для облегчения понимания следует привести только один факт: разрыв между очень богатыми и очень бедными в Норвегии является самым низким во всем мире. Стоит обозначить, что в Норвегии вообще не существует такого понятия, как “очень бедный”, как и “очень богатый”, кстати. Каждый норвежец живет в обществе, соблюдая десять "законов Янте”, по которым "тебя, как индивидуума, не существует; есть только коллективный организм". И как в любом нормальном здоровом организме все составляющие сотрудничают вместе ради дальнейшего здоровья этого организма. Странно? Да. Радикально? Да. Но это работает? Да. Именно следуя такой логике, норвежцы построили практически идеальное место, где хотят жить все, куда стремятся мигранты и обездоленные. Норвегия стала неким “Эльдорадо” для жителей стран третьего и второго мира. Автор предлагает в данной статье ознакомиться с основными составляющими норвежского "идеального социализма", предпосылками, побудившими руководство государства двигаться тем или иным путем, а также перечислить некоторые наиболее значимые социально ориентированные инновационные проекты Норвегии.

Ключевые слова: Норвегия, социальные инновации, закон Янте, возобновляемая энергетика, рыболовство.

\section{INFORMATION ABOUT THE AUTHOR}

Balanchuk I.S. - Senior Researcher of Ukrainian Institute of Scientific, Technical Expertise and Information, 180, Antonovicha Str., Kyiv, Ukraine, 03680; +38 (044) 521-09-81; balanchuk@uintei.kiev.ua; ORCID: 0000-00025179-7350

\section{ІНФОРМАЦІЯ ПРО АВТОРА}

Баланчук Ірина Сергіївна - с.н.с. Українського інституту науково-технічної експертизи та інформації, вул. Антоновича, 180, м. Київ, Україна, 03680; +38 (044) 521-09-81; balanchuk@uintei.kiev.ua; ORCID: 00000002-5179-7350

\section{ИНФОРМАЦИЯ ОБ АВТОРЕ}

Баланчук И.С. - с.н.с. Украинского института научно-технической экспертизы и информации, ул. Антоновича, 180, г. Киев, Украина, 03680; +38 (044) 521-09-81; balanchuk@uintei.kiev.ua; ORCID: 0000-0002-5179-7350

Л.В. ВОЛОШЕНЮК, С.Н.С.

Н.І. ГОРНОСТАЙ, С.Н.С.

О.Є. МИХАЛЬЧЕНКОВА, ЗаВВіДДіЛУ

\section{ІННОВАЦІЙНЕ ПІДПРИЄМНИЦТВО ЯК ЕФЕКТИВНИЙ МЕХАНІЗМ ТРАНСФЕРУ ТЕХНОЛОГІЙ В ІЗРАЇЛІ}

Резюме. У статті авторами виявлено, яким чином здійснюється передача технологій з університетів у бізнес
і відбувається усунення “розриву на рівні розробки” в Ізраїлі. Проаналізовано політику, моделі та принципи
у сфері передачі технологій, механізми стимулювання передачі науковими співробітниками технологій біз-
несу. Вивчено те, яким чином реалізується підприємницька ініціатива дослідних установ Ізраїлю. Підтримка
передачі технологій надається декількома способами. Одним із них є цільові програми, які спрямовані на
стимулювання взаємодії наукової спільноти та бізнесу, що проводиться за ініціативою уряду в особі Управ-
ління Головного вченого і за його фінансової підтримки. Ще один механізм стимулювання передачі науко-
вими співробітниками технологій бізнесу - це звільнення від сплати податків. Найчастіше підприємницька
ініціатива у сфері технологій може бути реалізована без всебічної участі дослідника-винахідника. у таких
випадках компанія-ліцензіат бере на себе керівництво процесом розробки технології та продукту. Моделі 